UDC 625.06:504.064:658.567.3

\author{
E.B. Khobotova ${ }^{a}$, V.I. Larin ${ }^{b}$, Yu.S. Kaliuzhna ${ }^{c}$, O.G. Storchak ${ }^{a}$
}

\title{
SLAG-ALKALINE BINDERS BASED ON DUMP WASTE BLAST FURNACE SLAG
}

\author{
${ }^{a}$ Kharkiv National Automobile and Highway University, Kharkiv, Ukraine \\ ${ }^{\text {b }}$ Research Institute of Chemistry, V.N. Karazin Kharkiv National University, Kharkiv, Ukraine \\ c Kharkiv Hydrometeorological Technical School, Odessa State Environmental University, Kharkiv, \\ Ukraine
}

\begin{abstract}
The mineralogical composition of the samples of slag-alkaline binders prepared on the basis of blast-furnace slags and various alkaline components was determined. X-ray diffraction and electron-probe microscopy were used to investigate the slag-alkaline binders under consideration. The obtained results indicated the advisability of the utilization of dump blast furnace slag in the production of slag-alkaline binders that significantly expands the raw materials base of binders' fabrication and their nomenclature. It was determined that the mineralogical composition of slag-alkaline binders based on blast furnace slag dump occupy an intermediate position between the Portland cement and slag-alkaline binders based on granulated blast furnace slag. Sodium-containing phases, the products of hydration solidification, carbonates and anhydrous aluminum silicates of $\mathrm{Ca}$ and $\mathrm{Mg}$ are the main minerals of the solidification of slag-alkaline binders. The high activity of slagalkaline binders based on slags and soda-alkaline melt was observed.
\end{abstract}

Keywords: slag, mineral, slag-alkaline binder, solidification, strength, alkaline component.

DOI: $10.32434 / 0321-4095-2019-126-5-160-167$

\section{Introduction}

Efficient utilization of large tonnage industrial waste is one of the topical ecological problems. A promising approach to the use of slag in the construction industry can be its processing to fabricate a clinkerless binding material.

This paper deals with the utilization of metallurgy industry wastes, dump waste blast furnace slag, to produce slag-alkaline binders (SAB). The output of blast furnace slag, its composition and properties depend on the chemical and mineral composition of barren rock, iron ore, coke, sulfur content in the blast furnace charge, the nature of the recovery and thermal state of the blast furnace and the grade of meltable cast iron. The chemical composition of dump waste slag at various metallurgical plants in Ukraine appreciably varies.

Slag can become hard under normal conditions when it contains a considerable amount of hydraulically active phases [1]. The content of these phases in slags is usually insignificant and slags do not harden under normal conditions or when being steamed by air pressure or they can harden very slowly and have low strength. When ground slag reacts with water, it can harden due to the introduction of additive activators that contribute to the manifestation of potential binding properties [2,3]. The introduction of additive activators brings about the formation of hydrosilicates and hydroaluminium silicates that cause solidification and the synthesis of artificial stone.

Activators are thoroughly mixed with slag during their joint grinding (sulfate-slag and lime-slag binders) or mixing with water solutions (slag-alkaline binders).

The use of industrial wastes, namely dump waste blast furnace slag, in the construction industry is a promising approach to reduce production cost and ease a negative impact on the environment. A dump waste area decreases if wastes are processed. Research data about the use of dump waste blast furnace slag to produce slag-alkaline binders are limited [2-4]. The expediency of the utilization of dump waste blast furnace slag to produce SAB can be substantiated by the investigation of the chemical and mineralogical properties of slag, samples of SAB and the test of their activation.

The objective of this work is to prove the raw material value of dump waste blast furnace slag to

(C) E.B. Khobotova, V.I. Larin, Yu.S. Kaliuzhna, O.G. Storchak, 2019 
produce SAB. The tasks of the paper are as follows: - to substantiate the utilization of dump waste blast furnace slag and the by-product of caprolactam production (soda-alkaline fusion cake, SAFC) in the manufacture of $\mathrm{SAB}$;

- to determine the elemental, oxide and mineralogical composition of $\mathrm{SAB}$;

- to perform a comparative analysis of the activation of the SABs that are produced when using various slags, varying the nature of an alkaline component and changing the modes of solidification;

- to clarify the number of dump waste blast furnace slags to the most suitable ones to produce SAB.

This study deals with dump waste blast furnace slags from the Public Joint-Stock Company (PJSC) Dneprovskiy Metallurgical Plant (DMP), the PJSC Zaporizhstal, the Private Joint-Stock Company Mariupol Metallurgical Plant named after Illich (MMP), the PJSC Alchevsk Metallurgical Plant (AMP) and the PJSC ArcelorMittal Kryvyi Rig (ArcelorMittal). In the last plant, in addition to dump waste blast furnace slag, the granulated blast furnace slag is researched. The composition of slags was studied earlier [5-7]. According to the data, dump waste slags contain a number of amorphous substances [8] to be considered as raw material components for the production of SAB.

\section{Experimental}

The dispersion of blast furnace samples on granulometric fractions is made with a set of sieves.

The mineral composition of SAB was determined by the X-ray and phase analysis; the chemical elemental and oxide composition of SAB was established by the electron probe microanalysis using the scanning electron microscope JSM-6390 LV with the micro X-ray analysis system INCA.

The dump waste blast furnace slag under research was ground by a ball grinder to obtain the specific surface $S_{\text {sp. }}=2700-4950 \mathrm{~cm}^{2} / \mathrm{g}$. Mixing was made with water, $20 \%$ solution of $\mathrm{NaOH}$ and sodaalkaline fusion cake, which is a water solution having the mass fractions of components as follows: $33.7 \%$ of $\mathrm{Na}_{2} \mathrm{CO}_{3}$ and $0.71 \%$ of $\mathrm{NaOH}$. The mass fraction of $\mathrm{NaOH}$ was within a recommended range of 5$15 \%$ of slag mass for SAB [9]. The density of the solutions of alkaline components was within an optimum range of $\rho=1.15-1.20 \mathrm{~g} / \mathrm{cm}^{3}$ [9]. The determination of binding paste consistency was carried out by the method of the spread of a standard cone over a vibrating table. Vibration time was $20 \mathrm{~s}$. When the spread was over, the cone basis diameter was measured in two mutually perpendicular directions. If the cone diameter deviated from the standard of $170 \pm 5 \mathrm{~mm}$, the amount of solution in the binding paste was changed. The solution-slag ratio, which was obtained to have the cone diameter $170 \pm 5 \mathrm{~mm}$, was further used in tests.

The binding paste was used to form the cubes of $2 \times 2 \times 2 \mathrm{~cm}$ that were compacted on a laboratory vibrating table at a frequency of 3000 vibrations per minute. Solidification was performed in the cell of heat and humidity treatment at the temperature of $80-85^{\circ} \mathrm{C}$. The strength of SAB samples was measured using the press $\mathrm{P}-5$ that had three scales of sensitivity, $\mathrm{kN}: 0-10 ; 0-25$ and $0-50$. Pressing speed was 3 $\mathrm{mm} / \mathrm{min}$.

\section{Results and discussion}

Characteristics of blast furnace slags to manufacture $S A B$

We showed earlier $[10,11]$ that the main qualitative and quantitative criteria of the practical utilization of dump waste blast furnace slag during the manufacture of binding materials are as follows: the ratio of the oxides of main components; the relationship between the modular classification and the coefficient values; the saturation, hydraulically active minerals and radiation safety of a product. According to them, blast furnace slags and their separate fractions, which are prospective to manufacture $\mathrm{SAB}$, have been chosen as follows: dump waste blast furnace slags from DMP and ArcelorMittal without sieving, granulometric fractions $>20 \mathrm{~mm}$ (Zaporizhstal), 2.5-5.0 mm (MMP), >5 $\mathrm{mm}$ (AMP) and $>10 \mathrm{~mm}$ (ArcelorMittal) granulated slag. They have been recommended for utilization as the components of Portland slag cement $[10,11]$. The main properties of a blast furnace slag composition are given in Table 1 . It is advisable to use the slags having the basicity modulus $\mathrm{Mb}>1$ [9]. In this case, regardless of the solidification conditions of $\mathrm{SAB}$, the alkaline component of various groups can be used: $\mathrm{NaOH}$ (I group) and soda-alkaline fusion cake (II group). All slags contain a rather high content of hydraulically active minerals: bredigite, akermanite and pseudowollastonite (Table 1).

The quantitative characteristics of SAB are practically absent in literature. The activation modulus Ma [9], which is shown in Table 1, shows water resistance of pure alkaline binders in the system of oxides $\mathrm{R}_{2} \mathrm{O}-\mathrm{Al}_{2} \mathrm{O}_{3}-\mathrm{SiO}_{2}$. Therefore, the inconsistency between the $\mathrm{SAB}$ and the criterion $\mathrm{Ma}=0.5-0.85$ is not critical.

To confirm the interaction between slag minerals and the mixing agents (water and 20\% solution of $\mathrm{NaOH}$ ) that brings about water-resistant solidification products, the mineral composition of the slag binder (SB) samples was determined (Table 2). 
Table 1

Characteristics of slag-alkaline binders and fractions of blast furnace slags used for their manufacture

\begin{tabular}{|c|c|c|c|c|c|c|c|c|c|c|c|}
\hline \multirow{3}{*}{ No } & \multicolumn{6}{|c|}{ Slag } & \multicolumn{5}{|c|}{ Slag-alkaline binder } \\
\hline & \multirow{2}{*}{$\begin{array}{l}\text { Metallurgical } \\
\text { plant, fraction, } \\
\mathrm{mm}\end{array}$} & \multirow[t]{2}{*}{$\frac{\mathrm{CaO}}{\mathrm{SiO}_{2}}$} & \multirow[t]{2}{*}{$\mathrm{Ma}=\frac{\mathrm{Al}_{2} \mathrm{O}_{3}}{\mathrm{SiO}_{2}}$} & \multirow[t]{2}{*}{$\mathrm{Mb}$} & \multirow{2}{*}{$\begin{array}{c}\frac{\mathrm{Al}_{2} \mathrm{O}_{3}}{\mathrm{Na}_{2} \mathrm{O}} \\
\left(\mathrm{Na}_{2} \mathrm{O} \text { of }\right. \\
\text { alkaline } \\
\text { component })\end{array}$} & \multirow{2}{*}{\begin{tabular}{|c|} 
Mass \\
fraction of \\
hydraulically \\
active \\
minerals, $\%$
\end{tabular}} & \multicolumn{2}{|c|}{$\mathrm{Ma}=\frac{\mathrm{Al}_{2} \mathrm{O}_{3}}{\mathrm{SiO}_{2}}$} & \multicolumn{3}{|c|}{$\begin{array}{l}\mathrm{R}_{\text {comp. }}(\mathrm{MPa}) \text { under air-dry } \\
\text { hardening in a } 20 \% \\
\text { solution of } \mathrm{NaOH} / \text { in } \\
\text { soda-alkaline fusion cake } \\
\text { in a time span, day }\end{array}$} \\
\hline & & & & & & & $\begin{array}{c}\text { in a } 20 \% \\
\text { solution } \\
\text { of } \mathrm{NaOH}\end{array}$ & $\begin{array}{c}\text { in } \\
\text { water }\end{array}$ & 7 & 28 & 90 \\
\hline 1 & $\begin{array}{c}\text { DMP, average } \\
\text { specimen }\end{array}$ & 1.79 & 0.12 & 1.69 & $\frac{3.79}{4.74}=0.80$ & 28.5 & 0.13 & - & $\frac{4.13}{7.94}$ & $\frac{6.58}{10.34}$ & $\frac{10.08}{9.50}$ \\
\hline 2 & $\begin{array}{c}\text { ArcelorMittal, } \\
\text { granulated, }>10 \\
\text { mm/average } \\
\text { specimen }\end{array}$ & 3.67 & 0.15 & $\frac{4.07}{2.41}$ & $\frac{2.95}{5.10}=0.58$ & 9.5 & 0.15 & 0.165 & $\frac{14.05}{0.45}$ & $\frac{21.39}{18.35}$ & $\frac{18.25}{37.16}$ \\
\hline 3 & $\begin{array}{c}\text { ArcelorMittal, } \\
\text { dump waste, } \\
\text { average } \\
\text { specimen } \\
\end{array}$ & 3.14 & 0.12 & 1.33 & $\frac{1.91}{5.10}=0.37$ & 43.6 & 0.057 & 0.06 & $\frac{5.46}{19.90}$ & $\frac{8.87}{18.15}$ & $\frac{11.72}{28.68}$ \\
\hline 4 & $\begin{array}{c}\text { Zaporizhstal, } \\
>20 \\
\text { mm/average } \\
\text { specimen } \\
\end{array}$ & $\frac{2.17}{1.96}$ & $\frac{0.11}{0.14}$ & $\frac{1.99}{1.68}$ & $\frac{2.08}{5.65}=0.37$ & 42.0 & 0.13 & 0.13 & $\frac{4.25}{0.40}$ & $\frac{6.19}{5.71}$ & $\frac{9.98}{16.07}$ \\
\hline 5 & $\begin{array}{c}\text { MMP, } \\
2.5-5.0 \\
\text { mm/average } \\
\text { specimen } \\
\end{array}$ & $\frac{3.19}{2.23}$ & $\frac{0.19}{0.12}$ & $\frac{2.75}{2.14}$ & $\frac{3.18}{5.10}=0.62$ & 33.7 & 0.14 & - & $\frac{4.54}{1.40}$ & $\frac{7.02}{15.19}$ & $\frac{9.90}{25.58}$ \\
\hline 6 & $\begin{array}{c}\text { AMP, }>5 \\
\text { mm/average } \\
\text { specimen }\end{array}$ & 3.09 & 0.15 & $\frac{3.93}{2.33}$ & $\frac{3.05}{5.46}=0.56$ & 43.1 & 0.13 & 0.12 & $\frac{4.52}{1.81}$ & $\frac{7.19}{6.32}$ & $\frac{9.25}{15.54}$ \\
\hline
\end{tabular}

\section{$S A B$ activation}

The strength tests of slag cement (SC) in compression $\left(\mathrm{R}_{\text {comp }}\right)$ was conducted within the period of hardening of 7, 28 and 90 day. The following agents of slag mixing were used: water, a $20 \%$ solution of $\mathrm{NaOH}$ and soda-alkaline fusion cake. Table 1 demonstrates the activation results of a slag alkaline test that was performed using an alkaline agent and soda-alkaline fusion cake. As the slags under consideration contain a great amount of $\mathrm{CaO}$, which decreases the strength of SAB [9], the high $R_{\text {comp }}$ is not initially expected. All the specimens increase their strength over time, with the exception of the decrease of the $\mathrm{R}_{\text {comp }}$ of slag-alkaline cement (SAC) on the basis of slag from DMP, soda-alkaline fusion cake and granulated slag from ArcelorMittal. A drop in the strength of slag-alkaline concrete and other slag concretes under air-dry conditions over longlasting hardening time spans has been observed [9]. This can be a consequence of either the long-lasting stabilization of a structure from amorphous to stable crystalline or the depletion of amorphous slag reserves.

\section{$\mathrm{SAB}$ containing the alkaline agent $\mathrm{NaOH}$}

As mentioned above, the mass fraction of $\mathrm{NaOH}$ is $5-15 \%$ of the total mass of slag. It corresponds to either an intensification of the SAB activation by $1.5-2$ times or its maximum stabilization [9]. The comparison of the $\mathrm{R}_{\text {comp }}$ values for different kinds of SAC, which are manufactured using alkaline and other slags, indicates the advantage of granulated slag obtained from ArcelorMittal (Table 1). In this case, a high activation of SAC is manifested in the initial period of hardening and the final one $(18.25 \mathrm{MPa})$ in comparison with other kinds of SAC. The SAC that is manufactured using dump waste blast furnace slags is characterized by longer gain of strength. Over the solidification time of 90 days, the value of $R_{\text {comp }}$ increases more than two times for all kinds of SAC in comparison with the initial period. 
Results of X-ray and phase analysis of slag binders

Table 2

\begin{tabular}{|c|c|c|c|c|c|c|c|c|c|c|c|c|}
\hline \multirow{3}{*}{$\begin{array}{c}\text { Phase / Slag specimen, mixing agent, } \\
\text { hardening days }\end{array}$} & \multirow{3}{*}{\begin{tabular}{|c|} 
DMP \\
$\mathrm{NaOH}$ \\
90 \\
\end{tabular}} & \multicolumn{4}{|c|}{\begin{tabular}{|c|c|}
$\begin{array}{c}\text { ArcelorMittal, } \\
\text { granulated }\end{array}$ & $\begin{array}{c}\text { ArcelorMittal, } \\
\text { dump waste }\end{array}$ \\
\end{tabular}} & \multicolumn{2}{|c|}{ Zaporizhstal } & \multicolumn{2}{|c|}{ MMP } & \multicolumn{3}{|c|}{ AMP } \\
\hline & & $\mathrm{NaOH}$ & $\mathrm{H}_{2} \mathrm{O}$ & $\mathrm{NaOH}$ & $\mathrm{H}_{2} \mathrm{O}$ & $\mathrm{NaOH}$ & $\mathrm{H}_{2} \mathrm{O}$ & $\mathrm{NaOH}$ & $\mathrm{NaOH}$ & $\mathrm{NaOH}$ & $\mathrm{NaOH}$ & $\mathrm{H} \mathrm{H}_{2} \mathrm{O}$ \\
\hline & & 90 & 90 & 90 & 90 & 90 & 90 & 90 & 28 & 90 & 28 & 90 \\
\hline Helenite $\mathrm{Ca}_{2} \mathrm{Al}\left(\mathrm{Al}, \mathrm{Si}_{2}\right)_{2} \mathrm{O}_{7}$ & 35.0 & 4.2 & 7.2 & & 1.5 & 17.8 & 30.7 & 30.5 & 37.5 & 29.7 & 24.5 & 27.0 \\
\hline Pseudowollastonite $\mathrm{CaSiO}_{3}$ & 15.0 & 3.1 & 3.9 & & & 9.7 & 10.0 & 12.1 & 12.0 & 11.9 & 11.2 & 11.5 \\
\hline Rankinite $\mathrm{Ca}_{3} \mathrm{Si}_{2} \mathrm{O}_{7}$ & 14.2 & 7.3 & 6.0 & 10.3 & 10.0 & 22.9 & 22.5 & 12.4 & 11,4 & 16.7 & 10.9 & 16.4 \\
\hline Bredigite $\mathrm{Ca}_{14} \mathrm{Mg}_{2}\left(\mathrm{SiO}_{4}\right)_{8}$ & 19.3 & 5.2 & 9.6 & 16.0 & 2.8 & 3.6 & 4.1 & 15.1 & 9.2 & 7.4 & 6.7 & 10.7 \\
\hline Akermanite $\mathrm{Ca}_{2} \mathrm{MgSi}_{2} \mathrm{O}_{7}$ & 9.1 & 6.8 & 6.3 & & & 10.1 & 7.6 & 6.7 & 6.6 & 9.0 & 9.1 & 11.2 \\
\hline * Calcite $\mathrm{CaCO}_{3}$ & 7.5 & 7.5 & 8.4 & & 7.7 & & & & & & & \\
\hline * Microcline $\mathrm{KAlSi}_{3} \mathrm{O}_{8}$ & & & & & & 8.6 & 8.5 & 2.1 & 4.2 & 2.1 & 11.5 & $\overline{7.3}$ \\
\hline Halite $\mathrm{NaCl}$ & & 28.0 & 32.1 & & & & & & & & & \\
\hline Larnite $\beta-\mathrm{Ca}_{2}\left(\mathrm{SiO}_{4}\right)$ & & 27.0 & 11.1 & 10.1 & 16.1 & & & & & & & \\
\hline Quartz $\mathrm{SiO}_{2}$ & & 2.4 & 5.4 & & & 1.2 & 2.8 & 0.27 & 3.0 & & & \\
\hline Parawollastonite $\mathrm{CaSiO}_{3}$ & & 5.3 & 5.9 & & & & & & & & & \\
\hline * Devitrite $\mathrm{Na}_{2} \mathrm{Ca}_{3} \mathrm{Si}_{6} \mathrm{O}_{16}$ & & 3.1 & 2.9 & & & & & & & & & \\
\hline$\alpha-\mathrm{Ca}_{2}\left(\mathrm{SiO}_{4}\right)$ & & & 1.3 & & & & & & & & & \\
\hline Hatrurite $\mathrm{Ca}_{3} \mathrm{SiO}_{5}$ & & & & 11.1 & 10.6 & & & & & & & \\
\hline $\begin{array}{l}{ }^{*} \text { Hydroandradite } \\
\mathrm{Ca}_{3} \mathrm{Fe}_{2} \mathrm{Si}_{1.15} \mathrm{O}_{4.6}(\mathrm{OH})_{7.4}\end{array}$ & & & & 13.2 & & & & & & & & \\
\hline${ }^{*} \mathrm{Ca}_{4} \mathrm{Al}_{2}(\mathrm{OH})_{12}\left(\mathrm{CO}_{3}\right)\left(\mathrm{H}_{2} \mathrm{O}\right)_{5}$ & & & & 21.0 & & 1.0 & & & & & & \\
\hline Clinoenstatite $\mathrm{MgSiO}_{3}$ & & & & 8.1 & 7.7 & & & & & & & \\
\hline Hematite $\mathrm{Fe}_{2} \mathrm{O}_{3}$ & & & & 3.9 & 2.0 & & & & & & & \\
\hline * Foshagite $\mathrm{Ca}_{4}\left(\mathrm{Si}_{3} \mathrm{O}_{9}\right)(\mathrm{OH})_{2}$ & & & & 2.4 & & & & & & & & \\
\hline $\mathrm{Ca}_{2} \mathrm{Fe}_{9} \mathrm{O}_{13}$ & & & & 2.5 & 5.1 & & & & & & & \\
\hline $\mathrm{Ca}_{2} \mathrm{Fe}_{22} \mathrm{O}_{33}$ & & & & 1.2 & & & & & & & & \\
\hline * Dellaite $\mathrm{Ca}_{6}\left(\mathrm{Si}_{2} \mathrm{O}_{7}\right)\left(\mathrm{SiO}_{4}\right)(\mathrm{OH})_{2}$ & & & & & 15.9 & & & & & 2.4 & 1.1 & 5.7 \\
\hline $\mathrm{Ca}_{3} \mathrm{Al}_{2} \mathrm{O}_{6}$ & & & & & 3.2 & & & & & & & \\
\hline $\begin{array}{l}\text { * Richterite } \\
\mathrm{K}_{0.954}\left(\mathrm{Ca}_{1.02} \mathrm{Na}_{0.98}\right) \mathrm{Mg}_{5} \mathrm{Si}_{8} \mathrm{O}_{22}(\mathrm{OH})_{2}\end{array}$ & & & & & 8.1 & & & & & & & \\
\hline Mayenite $(\mathrm{CaO})_{12}\left(\mathrm{Al}_{2} \mathrm{O}_{3}\right)_{7}$ & & & & & 0.6 & & & & & & & \\
\hline $\begin{array}{l}\text { * Fluorapophyllite } \\
\mathrm{KCa}_{4} \mathrm{Si}_{8} \mathrm{O}_{20} \mathrm{~F}\left(\mathrm{H}_{2} \mathrm{O}\right)_{8}\end{array}$ & & & & & 2.0 & & & & & & & \\
\hline Srebrodolskite $\mathrm{Ca}_{2} \mathrm{Fe}_{2} \mathrm{O}_{5}$ & & & & & 4.8 & & & & & & & \\
\hline $\begin{array}{l}\text { * Vesuvianite } \\
\mathrm{Ca}_{19.06}\left(\mathrm{Al}_{8.82} \mathrm{Mg}_{2.71} \mathrm{Fe}_{1.45} \mathrm{Ti}_{0.16}\right)\left(\mathrm{SiO}_{4}\right)_{10} \\
\left(\mathrm{Si}_{2} \mathrm{O}_{7}\right)_{4} \mathrm{O}(\mathrm{OH})\left((\mathrm{OH})_{6.56} \mathrm{~F}_{1.44}\right)\end{array}$ & & & & & 1.8 & & & & & & & \\
\hline * Killalaite $\mathrm{Ca}_{6.43} \mathrm{Si}_{4} \mathrm{O}_{16} \mathrm{H}_{3.17}$ & & & & & & 12.1 & 7.2 & 9.0 & 11.0 & 7.1 & 11.9 & 5.3 \\
\hline Hibonite $\mathrm{Al}_{6} \mathrm{CaFe}_{6} \mathrm{O}_{19}$ & & & & & & 5.0 & 1.6 & & & 1.5 & & 1.2 \\
\hline * Donpeacorite $(\mathrm{Mn}, \mathrm{Mg}) \mathrm{MgSi}_{2} \mathrm{O}_{6}$ & & & & & & 2.8 & & & & & & \\
\hline * Dolomite $\mathrm{Ca}\left(\mathrm{Ca}_{0.13} \mathrm{Mg}_{0.87}\right)\left(\mathrm{CO}_{3}\right)_{2}$ & & & & & & 5.2 & 2.8 & 0.8 & 1.2 & 1.8 & & 2.1 \\
\hline * Gismondine $\mathrm{CaAl}_{2} \mathrm{Si}_{2} \mathrm{O}_{8}\left(\mathrm{H}_{2} \mathrm{O}\right)_{4}$ & & & & & & & 2.2 & & & & & \\
\hline * Pyrssonite $\mathrm{CaNa}_{2}\left(\mathrm{CO}_{3}\right)_{2}\left(\mathrm{H}_{2} \mathrm{O}\right)_{2}$ & & & & & & & & 9.5 & 2.2 & 8.9 & 5.8 & \\
\hline $\begin{array}{l}\text { * Muscovite } \\
\mathrm{K}_{0.94} \mathrm{Na}_{0.06} \mathrm{Al}_{1.83} \mathrm{Fe}_{0.17} \mathrm{Mg}_{0.03} \\
\left(\mathrm{Al}_{0.91} \mathrm{Si}_{3.09} \mathrm{O}_{10}\right)(\mathrm{OH})_{1.65} \mathrm{O}_{0.12} \mathrm{~F}_{0.23}\end{array}$ & & & & & & & & 1.6 & 1.7 & 1.4 & 3.7 & 1.8 \\
\hline * Pectolite $\mathrm{HNaCa}_{2}\left(\mathrm{Si}_{3} \mathrm{O}_{9}\right)$ & & & & & & & & & & & 3.5 & \\
\hline * Hardening products of & $\frac{7.5}{925}$ & $\left|\begin{array}{c}10.6 \\
\text { without } \\
\mathrm{NaCl}\end{array}\right|$ & $\begin{array}{l}11.3 \\
16.6\end{array}$ & 36.6 & 35.5 & 29.7 & 20.7 & 23.0 & 20.3 & 23.7 & 37.5 & 22.2 \\
\hline $\mathrm{SAB} /$ aluminum silicates, & & $\frac{14.7}{85.3}$ & $\frac{10.0}{83.4}$ & $\overline{63.4}$ & $\overline{64.5}$ & $\overline{70.3}$ & $\overline{79.3}$ & $\overline{77.0}$ & $\overline{79.7}$ & $\overline{76.3}$ & $\overline{62.5}$ & $\overline{77.8}$ \\
\hline
\end{tabular}


It agrees with the results reported elsewhere [9] which have been received for various kinds of slag-alkaline concrete of natural solidification that dramatically increase the strength within the later period of the solidification. The highest strength properties are demonstrated by SAC containing dump waste slags from ArcelorMittal (11.72 MPa) and DMP (10.8 MPa). There is no direct correlation between the quantity of solidification products available in $\mathrm{SAB}$ and the strength of SAC specimens. All the SABs have high mass fractions of the aluminum silicates $\mathrm{Ca}$ and $\mathrm{Mg}$ that are more typical of Portland clinker hardening products (Table 2). For slag-alkaline cement on the basis of granulated slag ArcelorMittal, the fractions of similar solidification products are $14.7 \%$; the rest $(85.3 \%)$ is composed of water-resistant aluminum silicates of $\mathrm{Ca}$ and $\mathrm{Mg}$. By analogy, for slag-alkaline cement on the basis of dump waste slags from ArcelorMittal and DMP, the fractions are 63.4\% and $92.5 \%$, respectively. Therefore, the activation of the slag-alkaline cement is mainly stipulated by alkaline activation rather than a reaction with an alkaline agent.

$S A B$ containing alkaline agent of soda-alkaline fusion cake (SAFC)

Paper [9] reported that the basicity of slags increases the strength properties and improves other characteristics of slag-alkaline concrete. The economic inexpediency of caustic alkali as an activator was shown. This predetermines the practical use of soda, soda-based and soda-potash wastes from some industries as well as liquid glass. Owing to this, the strength properties of slag-alkaline cement containing dump waste slags and soda-alkaline fusion cake were determined. Table 1 demonstrates that the activation of slag-alkaline cement containing soda-alkaline fusion cake is higher than of $\mathrm{NaOH}$, which is very clearly manifested over the late periods of hardening. The compounds of sodium effect on the strength of the minerals of slags $C_{3} S$ and $\beta-C_{2} S$ can be ranged in the following series [9]:

$\mathrm{NaOH}<\mathrm{Na}_{2} \mathrm{CO}_{3}<\mathrm{Na}_{2} \mathrm{O} \cdot \mathrm{nSiO}_{2}<\mathrm{H}_{2} \mathrm{O}<\mathrm{Na}_{2} \mathrm{SO}_{4}<\mathrm{NaCl}$.

As slags mainly consist of bibasic and tribasic silicates of $\mathrm{Ca}$, an increase in $\mathrm{R}_{\text {comp }}$ for slag-alkaline cement and soda-alkaline fusion cake is understandable. When main slags and mixing agents (carbonates of alkaline metals) are used, an active reaction of cation exchange occurs, which causes the formation of the carbonates of alkali-earth metals and caustic alkalis.

Concerning the slag-alkaline cement containing dump waste slags and $\mathrm{NaOH}$, the use of slags having the lowest $\mathrm{Mo}(\mathrm{Mb}=1.33$ at ArcelorMittal and $\mathrm{Mb}=1.69$ at DMP) only contributes to the strength increase of slag-alkaline cement on the $90^{\text {th }}$ day of hardening. The higher the density of a mixing solution, the longer is the duration of the strengthening period of slag-alkaline concrete. The growth of $\mathrm{R}_{\text {comp }}$ for the slag-alkaline cement containing soda-alkaline fusion cake as compared with the slag-alkaline cement containing $\mathrm{NaOH}$ is predictable in the later time periods of solidification since $\rho_{\mathrm{SAFC}}=1.185 \mathrm{~g} / \mathrm{cm}^{3}>\rho_{\mathrm{NaOH}}=1.175 \mathrm{~g} / \mathrm{cm}^{3}$.

The strength of the slag-alkaline cement containing soda-alkaline fusion cake is also higher than that of the slag cement which was mixed with water. Because soda-alkaline fusion cake is a concentrated solution of $\mathrm{Na}_{2} \mathrm{CO}_{3}$ and $\mathrm{NaOH}$, the combined effect of two components seems to influence the strength properties causing the reversal of some sodium compounds.

The features of the specimen surface of slagalkaline binders, which are manufactured on the basis of soda-alkaline fusion cake and $\mathrm{Na}_{2} \mathrm{OnSiO}_{2}$, are studied by the raster electronic microscopy (Figure).

The slag-alkaline binders based on soda-alkaline fusion cake are characterized by a fine-crystalline surface structure and separate round shape pores that characterize the slag-alkaline binders containing various alkaline components. During the solidification, the recrystallization occurs that causes the disappearance of separate fine crystals, the formation of larger crystalline masses and a decrease in porosity (cf. photos a, b and c, d in Figure).

In case of the use of $\mathrm{Na}$ metasilicate as an alkaline component, the slag-alkaline binders are characterized by a higher density of structure and the lack of separate crystalline groups on a surface; a glassy phase is observed (photos $d$ and e in Figure). Structure cracking, which is more clearly pronounced in the slag-alkaline binders based on the dump waste slag ArcelorMittal, is typical.

The heat and humidity treatments of the slagalkaline binders change the hardening kinetics. The curves of the time dependence of the strength of most slag-alkaline binders containing water and alkaline change their shapes from convex (during natural hardening) to concave (during autoclaving). According to ref. [9], the strength of the slag-alkaline concrete is increased for a year and even longer. The slag-alkaline binders on the basis of dump waste slags from DMP and ArcelorMittal have $\mathrm{R}_{\text {comp }}=9-$ $10 \mathrm{MPa}$ for 24 hours of hardening. The slag-alkaline cement on the basis of other slags does not demonstrate a considerable increase in $\mathrm{R}_{\text {comp }}$ during the initial period of the solidification. Owing to this, 
it is inexpedient to recommend the heat and humidity treatments as a compulsory stage in slag-alkaline concrete manufacture.

Comparison with literature data shows that the slag-alkaline binders based on dump waste slags from ArcelorMittal, MMP, Zaporizhstal and AMP have the strength properties which are comparable with those of other SABs. Alkaline cement based on feldspars has strength of 2-5 MPa in 28 days [9]. Cement, that is manufactured using granulated blast furnace slag of ferrochromium, is characterized by the following values of strength in compression in 28 days (MPa): a separate slag binder 11.2 and a lime-slag cement 12.3 [12]. The slag-alkaline solutions of plastic containing granulated blast furnace slags in a ratio of one to three reach the strength in compression of 20-25 MPa under normal conditions of solidification. The strength of solutions and concrete increases to 35-60 MPa under steaming depending on the slag properties and the consumptions of SAB and an alkaline component [9]. The ultimate strength in compression of dump waste main foundry iron slags is $5-12.5 \mathrm{MPa}$ in 28 days when mixed with water [12]. According to the Ukrainian technical regulations [Building materials. Slag-alkaline binders. DSTU B V.2. 7-24-95], the ultimate strength in compression of slag-alkaline binders, which are manufactured using granulated blast furnace slag, will be $30 \mathrm{MPa}$ in 28 days. Considering the slag-alkaline binders under research, one can see that this demand is satisfied for most binders on the basis of dump waste blast furnace slags from ArcelorMittal and the 2.5-5.0 slag from MMP. These slags contain the highest content of hydraulically active minerals. If we take the standard value $(30 \mathrm{MPa})$ for $100 \%$, then $\mathrm{R}_{\text {comp }}$ reaches the following values for the abovementioned slags: $60.5 \%$ and $50.6 \%$ in 28 days and $95.6 \%$ and $85.3 \%$ in 90 days, respectively.

\section{Conclusions}

The suitability of the use of dump waste blast furnace slags to manufacture $\mathrm{SAB}$ was substantiated. This considerably expands the raw materials base of the production of SABs and their range of products.

The results demonstrated that the slag-alkaline binders on the basis of dump waste blast furnace slags are between Portland cement and the slagalkaline binders on the basis of granulated blast furnace slags in terms of mineralogical composition. The main minerals are sodium-containing phases, the products of hydration solidification, carbonates and anhydrous aluminosilicates of $\mathrm{Ca}$ and $\mathrm{Mg}$.

The highest activation of the slag-alkaline binders based on dump waste blast furnace slags from
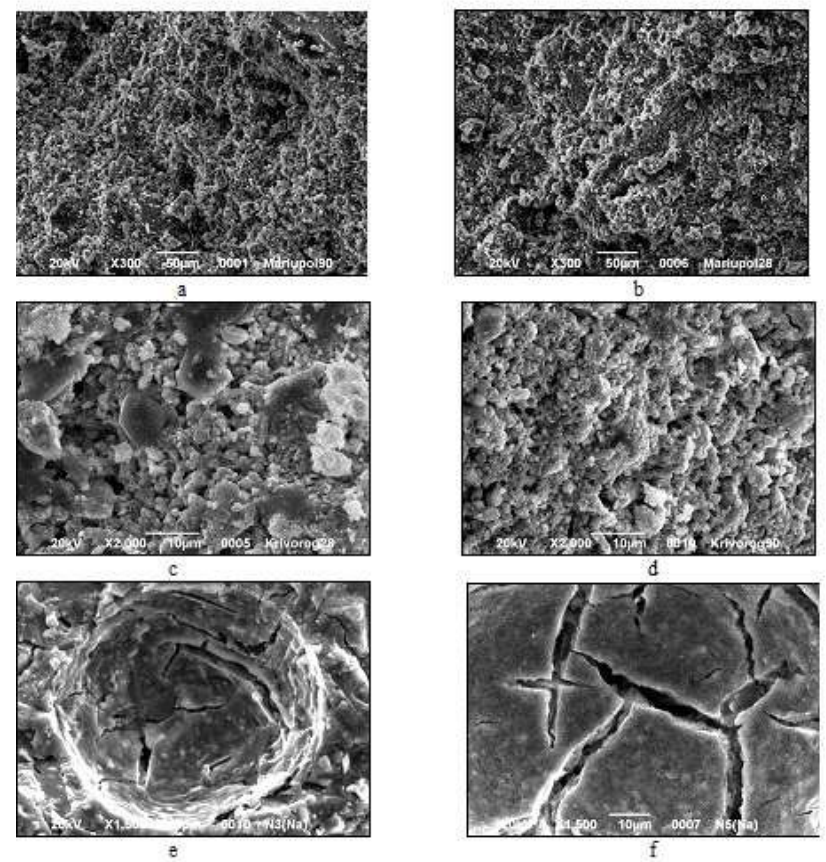

Microphotos of particle surface of SAB on the basis of dump waste blast furnace slags from MMP a, b, e and ArcelorMittal c, d, f. Alkaline components: a-d soda-alkaline fusion cake; e and f sodium metasilicate. Maturity interval (day): $\mathrm{a}, \mathrm{c}$, e and $\mathrm{f}-28$; $\mathrm{b}$ and $\mathrm{d}-90$

ArcelorMittal and a slag fraction of $2.5-5.0 \mathrm{~mm}$ from MMP was observed. The activation of SAB containing soda-alkaline fusion cake is higher than after mixing with the solutions of $\mathrm{NaOH}$ that is clearly manifested during the late periods of maturation.

\section{REFERENCES}

1. Jain $M$. Use and properties of blast furnace slag as a building material - a review / Mohit J. // International Journal of Recent Contributions from Engineering, Science \& IT (iJES). - 2014. - Vol.2. - No. 4. - P.54-60.

2. Pribulova A., Futas P., Baricova D. Processing and utilization of metallurgical slags / // Production Engineering Archives. - 2016. - Vol.11. - No. 2. - P.2-5.

3. Coarse blast furnace slag as a cementitious material, comparative study as a partial replacement of Portland cement and as an alkali activated cement / Escalante-Garcia J.I., EspinozaPerez L.J., Gorokhovsky A., Gomez-Zamorano L.Y. // Construction and Building Materials. - 2009. - Vol.23. - No. 7. - P.2511-2517.

4. Sajedi F., Razak H.A. The effect of chemical activators on early strength of ordinary Portland cement-slag mortars // Construction and Building Materials. - 2010. - Vol.24. No. 10. - P.1944-1951. 
5. Larin V.I., Khobotova E.B., Kalmykova Yu.S. The chemical composition of waste blast furnace slags // Ukrainskii Khimicheskii Zhurnal. - 2015. - V.81 - No. 6. - P.101-105.

6. Khobotova E. B., Kalmykova Yu. S. Protection of the environment during the disposal of blast-furnace blast-furnace slags in the production of building materials: monograph. Kharkov: HNADU, 2014. -225 p.

7. Khobotova E.B., Kalmykova Yu.S. Blast furnace slag as a raw material component of astringent veins // Ekologiya $i$ Promyshlennost'. - 2011. - No. 1. - P.35-40.

8. Kalmykova Yu.S., Larin V.I., Khobotova E.B. Rational ways of research of waste blast furnace slags // Energetyka: ekonomika, tekhnologiyi, ekologiya. - 2016. - No. 1. - P.4450 .

9. Glukhovsky V.D. Slag-alkaline binders and fine-grained concretes on their basis. -Tashkent: Uzbekistan, 1980. - $482 \mathrm{p}$.

10. Khobotova E.B., Kalmykova Yu.S., Fedorenko E.A. Use of blast-furnace slags in Portland cement production // Ekologiy Proizvodstva. - 2012. - No. 7. - P.61-66.

11. Khobotova E.B., Kalmykova Yu.S. Environmental and chemical grounds for the utilization of blast furnace slag in the production of binders // Russian Journal of General Chemistry. - 2012. - Vol.82. - No. 13. - P.10-18.

12. Budnikov P.P., Znachko-Yavorskii I.L. Granulated blastfurnace slags and slag cements. - Moskva: Promstroiizdat, 1953. $-223 \mathrm{p}$.

Received 01.02.2019

\section{ШЛАКОЛУЖНІ В'ЯЖУЧІ НА ОСНОВІ ВІДВАЛЬНОГО ДОМЕННОГО ШЛАКУ}

\section{Е.Б. Хоботова, В.І. Ларін, Ю.С. Калюжнна, О.Г. Сториак}

Визначено мінералогічний склад зразків шлаколужних в'яжучих, одержаних на основі відвальних доменних шлаків $i$ різних лужних компонентів. Використані такі методи дослідження: рентгенофазовий аналіз та електронно-зондова мікроскопія. Отримані результати свідчать про доцільність утилізації відвальних доменних шлаків у виробництві шлаколужних в'яжучих, що значно розширює сировинну базу виробництва в'яжучих матеріалів та їх номенклатуру. Визначено, що за мінералогічним складом шлаколужних в яжучих на основі відвальних доменних шлаків займають проміжне місие між портландцементами і шлаколужних в'яжучих на основі гранульованих доменних шлаків. Основними мінералами при твердінні шлаколужних в 'яжучих є фази, які містять натрій, продукти гідратаційного твердніння, карбонати і безводні алюмосилікати $\mathrm{Ca}$ i Mg. Зареєстрована висока активність шлаколужних в яжсчих на основі шлаків і содолужного плаву.

Ключові слова: шлак, мінерал, шлаколужне в'яжуче, твердіння, міцність, лужний компонент.

\section{SLAG-ALKALINE BINDERS BASED ON DUMP WASTE BLAST FURNACE SLAG}

\author{
E.B. Khobotova ${ }^{a,}{ }^{*}$, V.I. Larin ${ }^{b}$, Yu.S. Kaliuzhna ${ }^{c}$, \\ O.G. Storchak ${ }^{a}$
}

a Kharkiv National Automobile and Highway University, Kharkiv, Ukraine

b Research Institute of Chemistry, V.N. Karazin Kharkiv National University, Kharkiv, Ukraine

c Kharkiv Hydrometeorological Technical School, Odessa State Environmental University, Kharkiv, Ukraine

* e-mail: chemistry@khadi.kharkov.ua

The mineralogical composition of the samples of slag-alkaline binders prepared on the basis of blast-furnace slags and various alkaline components was determined. X-ray diffraction and electronprobe microscopy were used to investigate the slag-alkaline binders under consideration. The obtained results indicated the advisability of the utilization of dump blast furnace slag in the production of slag-alkaline binders that significantly expands the raw materials base of binders' fabrication and their nomenclature. It was determined that the mineralogical composition of slag-alkaline binders based on blast furnace slag dump occupy an intermediate position between the Portland cement and slag-alkaline binders based on granulated blast furnace slag. Sodium-containing phases, the products of hydration solidification, carbonates and anhydrous aluminum silicates of $\mathrm{Ca}$ and $\mathrm{Mg}$ are the main minerals of the solidification of slag-alkaline binders. The high activity of slag-alkaline binders based on slags and soda-alkaline melt was observed.

Keywords: slag; mineral; slag-alkaline binder; solidification; strength; alkaline component.

\section{REFERENCES}

1. Jain M. Use and properties of blast furnace slag as a building material - a review. International Journal of Recent Contributions from Engineering, Science \& IT (iJES), 2014, vol. 2, no. 4 , pp. 54-60.

2. Pribulova A., Futas P., Baricova D. Processing and utilization of metallurgical slags. Production Engineering Archives, 2016, vol. 11, no. 2, pp. 2-5.

3. Escalante-Garcia J.I., Espinoza-Perez L.J., Gorokhovsky A., Gomez-Zamorano L.Y. Coarse blast furnace slag as a cementitious material, comparative study as a partial replacement of Portland cement and as an alkali activated cement. Construction and Building Materials, 2009, vol. 23, pp. 2511-2517.

4. Sajedi F., Razak H.A. The effect of chemical activators on early strength of ordinary Portland cement-slag mortars. Construction and Building Materials, 2010, vol. 24, pp. 1944-1951.

5. Larin V.I., Khobotova E.B., Kalmykova Yu.S. The chemical composition of waste blast furnace slags. Ukrainskii Khimicheskii Zhurnal, 2015, vol. 81, pp. 101-105.

6. Khobotova E.B., Kalmykova Yu.S. Zashchita okruzhaushchei prirodnoi sredy pri utilizatsii otvalnykh domennykh shlakov $v$ proizvodstve stroitelnykh materialov [Protection of the environment during the disposal of blast-furnace blast-furnace slags in the production of building materials]. HNADU Publishers, Kharkiv, 2014. 225 p. (in Russian). 
7. Khobotova E.B., Kalmykova Yu.S. Otvalnyi domennyi shlak kak syrevoi komponent viyazhushchikh veshchestv [Blast furnace slag as a raw material component of astringent veins]. Ekologiya i Promyshlennost', 2011, no. 1, pp. 35-40. (in Russian).

8. Kalmykova Yu.S., Larin V.I., Khobotova E.B. Rational ways of research of waste blast furnace slags. Energetyka: Ekonomika, Tekhnologiyi, Ekologiya, 2016, no. 1, pp. 44-50.

9. Gluhovskii V.D., Shlakoshchelochnye vyazhushchie $i$ melkozernistye betony na ikh osnove [Slag-alkaline binders and fine-grained concretes on their basis]. Uzbekistan, Tashkent, 1980. 482 p. (in Russian).

10. Khobotova E.B., Kalmykova Yu.S., Fedorenko E.A. Ispolzovanie domennykh shlakov v proizvodstve portladtsementa [Use of blast-furnace slags in Portland cement production]. Ekologiya Proizvodstva, 2012, no. 7, pp. 61-66. (in Russian).

11. Khobotova E.B., Kalmykova Yu.S. Environmental and chemical grounds for the utilization of blast furnace slag in the production of binders. Russian Journal of General Chemistry, 2012, vol. 82 , pp. $10-18$.

12. Budnikov P.P., Znachko-Yavorskii I.L., Granulirovannye domennye shlaki i shlakovye tsementy [Granulated blast-furnace slags and slag cements]. Promstroiizdat Publishers, Moscow, 1953. 223 p. (in Russian). 